\title{
Pitriyazis Rosea Olgularında Otoimmün Belirteçlerin Araştırılması
}

\author{
Autoimmune Marker Prevalence in Pityriasis Rosea Patients \\ Bahar Sevimli Dikicier', Güneş Gür Aksoy ${ }^{2}$ \\ ${ }^{1}$ Sakarya Üniversitesi Eğitim ve Araştırma Hastanesi Deri ve Zührevi Hastalıklar ABD \\ ${ }^{2}$ Sağlık Bilimleri Üniversitesi Ankara Numune Eğitim ve Araştırma Hastanesi, Deri ve Zührevi Hastalıklar ABD \\ ORCID \\ Bahar Sevimli Dikicier: https://orcid.org/0000-0002-1912-394 \\ Güneș Gür Aksoy: https://orcid.org/0000-0002-4118-4243 \\ Yazışma Adresi / Correspondence: \\ Bahar Sevimli Dikicier \\ SSÜEAH, Korucuk kampüsü Dermatoloji kliniği Adapazarı, Sakarya \\ Tel: +90 5326469196 E-mail: bsevimlidikicier@gmail.com
}

Geliş Tarihi / Received : 30-03-2019 Kabul Tarihi / Accepted : 22-04-2019 Yayın Tarihi / Online Published: 30-04-2019

Sevimli Dikicier B., Gür Aksoy G.,Pitriyazis Rosea Olgularında Otoimmün Belirteçlerin Araştırılması

J Biotechnol and Strategic Health Res. 2019;3(1):33-37 DOİ:10.34084/bshr.547089

\begin{abstract}
$\ddot{\mathrm{O} z}$
Amaç Pitriyazis rosea (PR), ilk olarak 1798'de tanımlanmıs; akut, kendini sınırlayan bir papüloskuamöz deri hastalığıdır. Etiyolojisi halen açıklı̆a kavușmamıs olan PR, ilk tanımlandığından beri enfeksiyöz ajan-larla bağlantısından şüphelenilip bu konuda birçok araştırmanın yapıldığı, ancak kesin bir sonuca varılamadığı bir hastalıktır. Etiyopatogenezdeki rolleri açısından otoimmünite, genetik yatkınlık ve atopi ise halen araştırılmakta olan diğer faktörlerdir. Bu çalışmada PR etyopatogenezinde otoimmünit-enin rolünü değerlendirmek amacı ile tanı alan hastalarda (anti-nükleer antikor) ANA prevalansının araștırılması amaçlanmıștır.

Gereç ve Bu çalışmada, PR tanısı almış 46 hasta ve 26 sağlıklı kontrol dahil edilmiş olup bireylerde kanda, otoimmün belirteçlerden tarama testi olarak kabul edilen anti-nükleer Yöntemler antikor (ANA- indirect İFA Hep-2 BioSystems囚) prevalansı araștırılmıștır. ANA pozitiflerde antistreptolizin-o (ASO), C-reaktif protein (CRP), romatoid faktör (RF), IgG, IgM, IgA, kompleman 3 ve 4 (C3 ve C4) düzeyleri de ne-felometrik yöntemle; anti SSA (Ro), anti SSB (La), anti dsDNA, antihiston, anti U1RNP, anti Jo1, anti sentromer, anti-Scl-70, antisentromer antikor (ANCA), anti mitokondriyal, anti düz kas, anti Rib P protein, anti tiroglobulin (anti TG), anti tiroid peroksidaz antikor (anti TPO) testleri de immünblot-ting yöntemiyle araștırılmıștır.

Bulgular PR'li hastaların 4'ünde $(\% 8,7)$ ANA $(+)$ iken kontrol grubunda hepsi negatif saptanmış olup gruplar arası fark anlamlı bulunmuștur ( $<<0.05)$. Ancak istatistiksel olarak ANA pozitifliği ile PR arasında anlamlı ilişki bulunmamıştır.

Sonuç Çalışmamızda PR hastalarında saptanan ANA prevalansı istatistiksel olarak anlamlı bulunsa da top-lumda sağlıklı kişilerde de beklenen ANA prevalansı (\%4-5) benzer oranlarda saptanabildiği için PR patogenezinde otoimmünitenin rolünü inceleyen daha geniş kapsamlı çalışmalara gereksinim vardır.

Anahtar Pitriyazis rosea, otoimmünite, papüloskuamöz döküntü

Kelimeler
\end{abstract}

Abstract

Objective Pityriasis rosea (PR) is an acute, self-limited papulo-squamous disorder which was described in 1798, firstly. The etiology of PR is unknown, infectious etiology has been the most investigated subject but no exact infectious origin is identified to date. Autoimmunity, genetic predisposition and atopi are the other subject matters which have been investigated. The prevalence of anti-nuclear antibody (ANA) was investigated in PR patients to evaluate the potential role of autoimmunity in etiopathogenesis of PR.

Materials and Fourty six PR patients and 24 healthy control individuals were included in this study and the preva-lence of serum anti-nuclear antibody (ANA- indirect IFA Hep-2 BioSystems $\bowtie)$ which is Methods the screening test for autoimmunity, was compared between these groups. Serum antistreptolysin-o (ASO), C-reactive protein (CRP), romatoid factor (RF), IgG, IgM, IgA, complement 3 ve 4 (C3 ve C4) levels were detected with nephelometric study, anti SSA (Ro), anti SSB (La), anti dsDNA, antihiston, anti U1RNP, anti Jol, anti centromere, anti-Scl-70, anticentromere antibody (ANCA), anti mitochondrial, anti smooth muscle, anti Rib P protein, anti thyroglobulin (anti TG), anti thyroid peroxidase antibody (anti TPO) levels were detected with immunoblotting method for the ANA (+) participants.

Results ANA prevalence was $8,7 \%$ in PR group, where as it was 0 , in the control group $(p<0.05)$.

Conclusion ANA prevalence of $8,7 \%$ among PR patients is statistically significant, but this rate is similar with the expected ANA prevalence among healthy population which is $4-5 \%$. Further larger studies are needed to evaluate the part of autoimmunity in etiopathogenesis of PR.

Keywords Pityriasis rosea, autoimmunity, papulosquamous eruption 


\section{GIIRIŞ}

Pitriyazis rosea (PR), ilk olarak 1798'de "gittikçe çoğalan küçük, ince kepekli düzensiz yama-lar” olarak tanımlanmış; akut, kendini sınırlayan bir papuloskuamöz deri hastalığıdır'1 1860’ta Fransız dermatolog Camille Melchior Gibert tarafından pitriyazis rozea olarak isimlendirilmiştir $^{2}$.

PR her ırkta görülmektedir. Genel prevalansı kadınlarda $\% 0,13$, erkeklerde $\% 0,14$ tür. Farklı dermatoloji merkezlerindeki insidansı ise \%0,3 ile \%3 arasında değişir. Her iki cinsi eşit olarak etkiler ${ }^{3,4}$.

PR’nin görüldüğü yaş aralığı 10-43 yaşlardır. Olguların \%75’i 10-35 yaşlar arasındadır. Üç aylık bir infantta ve 83 yaşında bir bireyde görüldüğü de bildirilmiştir. En sık ilkbahar ve sonbahar veya yılın soğuk dönemlerinde görülmektedir"

Etiyolojisi halen açıklığa kavuşmamış olan PR, ilk tanımlandığından beri enfeksiyöz ajanlarla bağlantısından şüphelenilip bu konuda birçok araştırmanın yapıldığı, ancak kesin bir sonuca varılamadığı bir hastalıktır 5. Etiyopatogenezdeki rolleri açısından otoimmünite, genetik yatkınlık ve atopi ise halen araştırılmakta olan diğer faktörlerdir 6 . Human Herpesvirus 6 (HHV-6) ve Human Herpesvirus 7 (HHV-7) birçok çalışmada etiyolojik açıdan araştırılmış, ulaşılabilen sadece iki çalışmada PR'nin sistemik aktif HHV-6 ve HHV-7 enfeksiyonuyla olabileceği sonucuna varılmıştır ${ }^{7,8}$. Diğer araştırmacılarının çoğu tarafından bu bilgi doğrulanmamışııิ'-13.

Bazı araştırmacılar PR patogenezinde otoimmün mekanizmalardan şüphelenmişler ve genetik olarak yatkın kişilerde ortaya çıkan oto-agresif bir hastalık olabileceğini öne sürmüşlerdir ${ }^{14}$. PR’nın otoimmün belirteçlerle ilgisini araştırmaya yönelik vaka kontrollü bir çalışmada 18 PR'lı hasta ve 18 sağlıklı bireyle karşılaştırılmış, PR'lı gruptan 5 hastada (\%27.8) önemli titrelerde ANA (antinükleer antikor) pozitifliği saptanırken kontrol grubu hiçbir bireyde
ANA pozitifliği bildirilmemiştir ${ }^{15,16}$.

Bu çalışmada PR tanısı alan hastalarda otoimmün belirteçlerden ANA’nın bir tarama testi olarak kullanılmasının irdelenmesi amaçlanmıştır.

\section{MATERYAL ve METOT}

Çalışmaya, etik kurul onay sonrası, Sağlık Bakanlığı Ankara Numune Eğitim ve Araştırma Hastanesi Deri ve Zührevi Hastalıklar Polikliniğine başvuran amamnez ve dermatolojik muayene ile PR tanısı almış 46 hasta ve 26 sağlıklı control dahil edilmiştir.

Dermatoloji polikliniğine başvurup klinik olarak PR tanısı alan, eşlik eden başka dermatolojik ve sistemik hastalık öyküsü vermeyen hastalar çalışmaya dahil edildi.Tüm hastalara eşlik eden has-talıklar ve ilaç kullanımı sorgulanmış, tüm hastalara Venerial Diseases Research Laboratory (VDRL) tarama testi uygulanmıştır. Kontrol grubu olarak son iki yıldır herhangi bir döküntülü ya da sistemik hastalık öyküsü olmayan 26 sağlıklı birey seçilmiş ve hasta ve kontrol grubundaki tüm bireylerde kanda indirekt immünfloresan yöntemle kanda substrat olarak human epitelyal hücre 2 (Hep-2)' nin kullanıldığı kitlerle (BioSystems $囚)$ ANA pozitifliği aranmıştır. ANA pozitif saptanan bireylerde an-tistreptolizin-o (ASO), C-reaktif protein (CRP), romatoid faktör (RF), IgG, IgM, IgA, kompleman 3 ve 4 (C3 ve C4) düzeyleri de nefelometrik yöntemle araşt1rılmıştır. ANA pozitif hastalarda immünbot-ting yöntemle anti SSA (Ro), anti SSB (La), anti dsDNA, antihiston, anti U1RNP, anti Jo1, anti sen-tromer, anti-Scl-70, antisentromer antikor (ANCA), anti mitokondriyal, anti düz kas, anti Rib P pro-tein, anti tiroglobulin (anti TG), anti tiroid peroksidaz antikor (anti TPO) varlı̆̆ da araştırılmıştır. Sonuçların istatistiksel değerlendirmesi SPSS paket programı ile Fisher’s Exact Test ile yapılmıştır.

\section{BULGULAR}

Hasta grubunun 26'sı kadın (\%56,5), 20'si erkek (\%43,5), kontrol grubu bireylerinin 14'ü $(\% 58,5)$ kadın, 10’u 
$(\% 41,7)$ erkeklerden oluşmuştur. Hasta grubunda yaş ortalaması 26.4 (11-49), kontrol grubunda 27,4 (13-47) olup gruplar arasında yaş cinsiyet açısından fark bulunmamıştır ( $\mathrm{p}=0.05)$ (Tablo 1). Hastaların hiç birinde ilaç kullanma öyküsü ve eşlik eden hastalık yoktu.

\begin{tabular}{|c|c|c|c|c|}
\hline & Kadın & & Erkek & \\
\hline & Sayı & $\%$ & Sayı & $\%$ \\
\hline HASTA & 26 & 56.5 & 20 & 43.5 \\
\hline KONTROL & 14 & 58.3 & 10 & 41.7 \\
\hline
\end{tabular}

PR'li hastaların 4'ünde ANA (+), kontrol grubunun ise hepsinde negatif bulunmuştur. ANA (+) saptanan hastaların diğer otoantikor ve inflamatuar belirteç düzeyleri tablo 2'de gösterilmiştir.

ANA (+) bulunan ilk hastada (25 y, erkek) anti SSA/Ro ve anti düz kas antikorları pozitif saptanmış, bu hastanın ASO ve RF düzeyleri de yüksek bulunmuştur. ANA (+) ikinci hasta 11 yaşında erkek olup p-ANCA ve c-ANCA testleri de pozitiftir. Pediatri bölümü tarafından konsülde edilen hasta herhangi bir tanı almamıştır. ANA (+) bulunan diğer hasta 31 yaşında kadın hasta olup Anti TG düzeyi yüksek fakat tiroid hormon profili normal düzeylerde saptanmıştır. Hasta gerekli konsültasyonlar sonrası Hashimato tiroiditi tanısı almıştır.

ANA (+) saptanan son olgunun(21 yaş, kadın) öyküsünde yüksek ateş, oral aft, saç dökülmesi ve Raynaud fenomeni olduğu, döküntülerden 4 hafta sonra başvuran hastanın 2 hafta önce ateş ve oral aft şikayetlerinin kaybolduğu öğrenilmiştir. Diğer oto antikor düzeyleri, akut faz reaktanları ve immün globülin düzeyleri normal olan hastanın takiplerinde Raynaud fenomeninin soğukla tetiklendiği gözlenmiştir, uzun dönem takiplerinde başka herhangi bir bulgu saptanmamıştır.

Hasta ve kontrol grubu arasında ANA pozitiflik oranların- da anlamlı farklılık saptanmıștır (Tablo 3).

\begin{tabular}{|c|c|c|c|c|c|c|c|c|c|c|c|c|c|c|c|c|}
\hline Tabl & 102. & PR 1 & lasta & arm & in oto & imm & ün $b$ & elirte & pro & ofili. & $K: K$ & adın & E: Er & rkek & & \\
\hline & $\approx$ & $\begin{array}{l}\text { 营 } \\
\text { 吾 }\end{array}$ & 䍃 & 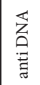 & 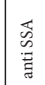 & \begin{tabular}{|l|}
$\infty$ \\
$\infty$ \\
$\tilde{z}$ \\
\end{tabular} & 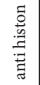 & 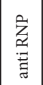 & $\begin{array}{l}\text { P } \\
\text { 离 } \\
\text { 声 }\end{array}$ & 苞 & $\begin{array}{l}\text { 节 } \\
\text { 㝵 }\end{array}$ & $\begin{array}{l}\text { 辛 } \\
\text { 表 }\end{array}$ & $\begin{array}{l}\tilde{\Xi} \\
\bar{z} \\
\tilde{z}\end{array}$ & $\begin{array}{l}\text { 芖 } \\
\text { 胥 }\end{array}$ & $\begin{array}{l}0 \\
\stackrel{.}{E} \\
\vec{z}\end{array}$ & 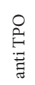 \\
\hline 1 & 27 & K & & & & & & & & & & & & & & \\
\hline 2 & 27 & E & & & & & & & & & & & & & & \\
\hline 3 & 17 & $\mathrm{E}$ & & & & & & & & & & & & & & \\
\hline 4 & 49 & $\mathrm{E}$ & & & & & & & & & & & & & & \\
\hline 5 & 42 & E & & & & & & & & & & & & & & \\
\hline 6 & 20 & $\mathrm{~K}$ & & & & & & & & & & & & & & \\
\hline 7 & 24 & $\mathrm{E}$ & & & & & & & & & & & & & & \\
\hline 8 & 25 & $\mathrm{E}$ & + & - & + & - & - & - & - & - & - & - & - & + & - - & - \\
\hline 9 & 32 & $\mathrm{~K}$ & & & & & & & & & & & & & & \\
\hline 10 & 43 & $\mathrm{~K}$ & & & & & & & & & & & & & & \\
\hline 11 & 15 & $\mathrm{E}$ & & & & & & & & & & & & & & \\
\hline 12 & 14 & $\mathrm{E}$ & & & & & & & & & & & & & & \\
\hline \begin{tabular}{|l|}
13 \\
\end{tabular} & 31 & $\mathrm{~K}$ & & & & & & & & & & & & & & \\
\hline \begin{tabular}{l|l}
14 \\
\end{tabular} & 26 & $\mathrm{E}$ & & & & & & & & & & & & & & \\
\hline 15 & 24 & $\mathrm{~K}$ & & & & & & & & & & & & & & \\
\hline \begin{tabular}{l|l}
16 \\
\end{tabular} & 22 & $\mathrm{~K}$ & & & & & & & & & & & & & & \\
\hline \begin{tabular}{ll|}
17 \\
\end{tabular} & 11 & $\mathrm{E}$ & + & - & - & - & - & - & - & + & - & - & - & - & - & - \\
\hline \begin{tabular}{|l|}
18 \\
\end{tabular} & 26 & E & & & & & & & & & & & & & & \\
\hline \begin{tabular}{l|l|}
19 \\
\end{tabular} & 25 & $\mathrm{E}$ & & & & & & & & & & & & & & \\
\hline 20 & 33 & $\mathrm{~K}$ & & & & & & & & & & & & & & \\
\hline 21 & 27 & E & & & & & & & & & & & & & & \\
\hline 22 & 23 & $\mathrm{~K}$ & & & & & & & & & & & & & & \\
\hline 23 & 19 & $\mathrm{E}$ & & & & & & & & & & & & & & \\
\hline 24 & 30 & $\mathrm{~K}$ & & & & & & & & & & & & & & \\
\hline 25 & 22 & $\mathrm{~K}$ & & & & & & & & & & & & & & \\
\hline 26 & 26 & $\mathrm{E}$ & & & & & & & & & & & & & & \\
\hline 27 & 36 & E & & & & & & & & & & & & & & \\
\hline 28 & 23 & $\mathrm{~K}$ & & & & & & & & & & & & & & \\
\hline 29 & 25 & $\mathrm{~K}$ & & & & & & & & & & & & & & \\
\hline 30 & 22 & $\mathrm{E}$ & & & & & & & & & & & & & & . \\
\hline 31 & 33 & $\mathrm{~K}$ & & & & & & & & & & & & & & \\
\hline 32 & 31 & $\mathrm{~K}$ & + & - & - & - & - & - & - & - & - & - & - & - & + & + \\
\hline 33 & 21 & $\mathrm{~K}$ & + & - & - & - & - & - & - & - & - & - & - & - & - & - \\
\hline 34 & 43 & $\mathrm{~K}$ & & & & & & & & & & & & & & \\
\hline 35 & 28 & $\mathrm{~K}$ & & & & & & & & & & & & & & \\
\hline \begin{tabular}{l|l}
36 \\
\end{tabular} & 28 & $\mathrm{~K}$ & & & & & & & & & & & & & & \\
\hline 37 & 24 & $\mathrm{~K}$ & & & & & & & & & & & & & & \\
\hline 38 & 12 & $\mathrm{~K}$ & & & & & & & & & & & & & & \\
\hline 39 & 25 & $\mathrm{~K}$ & & & & & & & & & & & & & & \\
\hline 40 & 24 & $\mathrm{~K}$ & & & & & & & & & & & & & & \\
\hline 41 & 19 & E & & & & & & & & & & & & & & \\
\hline 42 & 17 & $\mathrm{~K}$ & & & & & & & & & & & & & & \\
\hline \begin{tabular}{l|l}
43 \\
\end{tabular} & 30 & $\mathrm{~K}$ & & & & & & & & & & & & & & \\
\hline 44 & 35 & K & & & & & & & & & & & & & & \\
\hline 45 & 32 & $\mathrm{E}$ & & & & & & & & & & & & & & \\
\hline 46 & 28 & $\mathrm{E}$ & & & & & & & & & & & & & & \\
\hline
\end{tabular}




\begin{tabular}{|c|c|c|c|c|}
\hline \multicolumn{5}{|c|}{$\begin{array}{l}\text { Tablo 3. Hasta ve kontrol grubunun ANA pozitiflik } \\
\text { oranları. }\end{array}$} \\
\hline & \multicolumn{2}{|c|}{ ANA + } & \multicolumn{2}{|c|}{ ANA - } \\
\hline & Say1 & $\%$ & Say1 & $\%$ \\
\hline HASTA & 4 & 8.7 & 42 & 91.3 \\
\hline KONTROL & - & - & 24 & 100 \\
\hline
\end{tabular}

Tartışma

PR'sin otoagresif bir hastalık olabileceği görüşü ilk olarak 1970 Burch ve Rowell tarafından öne sürülmüştür. PR’nin klinik tablosuna ve geçirilmiş enfeksiyöz süreçle bağlantısına vurgu yaparak yeterli özgünlükte mikroorganizmaların konağa girişinin otoagresif/otoreaktif bir durumun ilk atağını başlatabileceğini öne sürmüşlerdir ${ }^{14}$.

1987'de Mısır'da yapılan çalışmada bu konuya odaklanılmış ve PR hastalarının immünolojik parametrelerinin incelendiği çalışmada PR'da döküntüye yol açan durumun virüs-antikor kompleksle-rinin dokuda birikimi sonucu başlayan immün yanıt olduğu yorumunu yapmışlardır. Serum IgM düzeyleri PR grubunda yüksek, C3 düzeyleri düşük bulunmuştur ${ }^{17}$.

Hosakawa ve ark. Yaptıkları çalışmada PR, viral ekzantem düşünülen hastalıklar, enfeksiyöz mononükleoz (EMN) ve rubella hastalarında pozitif kontrol grubu olarak Sistemik lupus eritematozus (SLE) hastalarını almışlar $\mathrm{T}$ lenfositotoksik antikor varlığını araştırmışlardır. SLE 'de \%82 bulunan T lenfositotoksik antikor insidansı PR'de \% 28, EMN'de \%44, rubellada \%8, viral ekzantemlerde \%28 oranında bulunmuştur. SLE dışındaki antikor titrelerinin düşük ve sürekliğin kısa olduğunu bild-irmişlerdir ${ }^{18}$.

$\mathrm{Bu}$ çalışmaya benzer şekilde, Chuh tarafından PR hastalarında yapılan çalışmada 18 hastanın 5 'inde , \%27,8 oranında ANA (+) saptanmış, bu sonuç istatistiksel olarak anlamlı değerlendirilmem-iştir, hasta sayısının azlığı da çalışmanın zayıf yanı olarak gösterilmiştir ${ }^{15}$. Ultraviyole B (UVB) nin PR'de etkinliğini araştıran placebo kontrollü bir çalışmada da anlamlı iyileşme görüldüğü bildirilmiş- tir ${ }^{19}$. Araştırmacılar UVB’nin PR'deki etkinliğini hücresel immünitenin baskılanması ve derideki Lang-erhans hücrelerinin sayı ve fonksiyonlarının modifikasyonunu sağlamasına bağlamışlardır ${ }^{19,20}$.

PR'nin viral etyolojinin kanıtlandığı diğer hastalıklara benzeyen programlanmış izlenimi veren tipik seyri, etyopatogenezde enfeksiyöz bir ajanın rol aldığını düşündürmektedir. Otoimmünitenin PR patogenezindeki rolü henüz bilinmemektedir. Otoimmünitenin temelinde genetik yatkınlık zemininde bazı çevresel faktörlerin başlattığı immün yanıt yatmaktadır. PR'nin otoimmün belirteçlerle birlikte olması durumu, bu olguların otoimmünite insidansının yüksek olduğu HLA DR haplotiplerini taşıma-ları olabilir. PR'yi viral bir enfeksiyon veya viral reaktivasyonla ortaya çıkaran bir genetik yaktınlık söz konusu olabilir ${ }^{6}$.

Sonuç olarak çalışmamızda 46 kişiden oluşan PR hastalarının 4'ünde \% 8,7 oranı ile ANA (+) saptanmıştır. Bu oran istatistiksel olarak anlamlı bulunsa da sağlıklı kişilerde beklenen ANA (+) prevalansı olan \%4-5 oranına benzerdir 15. Bu konuda yapılacak daha çok sayıda olgu içeren çok merkezli çalışmalara ihtiyaç vardır. 
Journal of BSHR 2019;3(1):33-37

DİKICIIER, AKSOY Pitriyazis Rosea Olgularında Otoimmün Belirteçlerin Araştırılması

\section{Kaynaklar}

1. Karnath B, Hussain N, Bevin M. Pityriasis rosea. Appearance and distribution of macules aid diag-nosis. Postgrad Med 2003;113(5): 93-4, 97.

2. Braun Falco O, Plewig G, Wolff HH, Burgdorf WHC. Dermatology. 2nd ed. Springer, Berlin, 2000; chapter 14: 435-439.

3. Chuh A, Zawar V, Lee A. Atypical presentations of pityriasis rosea: case presentations. J Eur Acad Dermatol Venereol. 2005; 19(1): 120-6.

4. Mosher DB, Fitzpatrick JB, Ortanne JP, Hori Y. Pityriasis Rosea. In: Freedberg IM, Eisen AZ, Wolff K, Austen KF, Goldsmith LA, Katz SF, Fitzpatrick JB, editors. Dermatology in general medi-cine. 6th ed. New York: McGraw Hill Company, 2004; 617-622.

5. Chuang TY, Perry HO, Ilstrup DM, Kurland LT. Recent upper respiratory tract infection and pity-riasis rosea: a case-control study of 249 matched pairs. Br J Dermatol. 1983 May;108(5):587-91.

6. Chuh A, Chan H, Zawar V. Pityriasis rosea--evidence for and against an infectious aetiology. Epi-demiol Infect. 2004 Jun;132(3):381-90.

7. Watanabe T, Kawamura T, Jacob SE, Aquilino EA, Orenstein JM, Black JB, Blauvelt A. Pityriasis rosea is associated with systemic active infection with both human herpesvirus-7 and human herpesvi-rus-6. J Invest Dermatol. 2002 Oct;119(4):793-7.

8. Drago F, Ranieri E, Malaguti F, Losi E, Rebora A. Human herpesvirus 7 in pityriasis rosea. Lan-cet. 1997 May 10;349(9062):1367-8.

9. Kempf W, Adams V, Kleinhans M, Burg G, Panizzon RG, Campadelli-Fiume G, Nestle FO. Pity-riasis rosea is not associated with human herpesvirus 7. Arch Dermatol. 1999 Sep;135(9):1070-2.

10. Yasukawa M, Sada E, MacHino H, Fujita S. Reactivation of human herpesvirus 6 in pityri- asis rosea. Br I Dermatol. 1999 Jan;140(1):169-70.

11. Offidani A, Pritelli E, Simonetti O, Cellini A, Giornetta L, Bossi G. Pityriasis rosea associa ted with herpesvirus 7 DNA. J Eur Acad Dermatol Venereol. 2000 Jul;14(4):313-4.

12. Karabulut AA, Koçak M, Yilmaz N, Eksioglu M. Detection of human herpesvirus 7 in pityriasis rosea by nested PCR. Int J Dermatol. 2002 Sep;41(9):563-7.

13. Chuh AA, Chiu SS, Peiris JS. Human herpesvirus 6 and 7 DNA in peripheral blood leucocytes and plasma in patients with pityriasis rosea by polymerase chain reaction: a prospective case control study.Acta Derm Venereol. 2001 Aug-Sep;81(4):289-90.

14. Burch PR, Rowell NR. Pityriasis rosea--an autoaggressive disease? Statistical studies in relation to aethiology and pathogenesis. Br J Dermatol. 1970 Jun;82(6):549-60.

15. Chuh AA. A prospective case control study of autoimmune markers in patients with pityriasis rosea. Clin Exp Dermatol. 2003 Jul;28(4):449-50.

16. Singh M, Pawar M, Chuh A, Zawar V. Pityriasis rosea: elucidation of environmental factors in modulated autoagressive etiology and dengue virus infection. ActaDermatovenerol Alp Pannonica Adriat. 2019 Mar;28(1):15-20.

17. Wilkinson SM, Smith RG, Danis MJ et al. Pityriasis rosea and discoid eczema: dose related reac-tions to treatment with gold. Ann Rheum Dis. 1992; 51: 881-884.

18. Hosokawa H, Horio S, Takiuchi Y, Maruyama N, Asada Y. Naturally occurring T lymphocyto-toxic antibody in viral and related skin diseases. Acta Derm Venereol. 1984;64(4):275-80.

19. Valkova S, Trashlieva M, Christova P. UVB phototherapy for Pityriasis rosea.J Eur Acad Dermatol Venereol. 2004 Jan;18(1):111-2.

20. Aiba S, Tagami H. Immunohistologic studies in pityriasis rosea. Evidence for cellular immune reaction in the lesional epidermis. Arch Dermatol. 1985 Jun;121(6):761-5. 